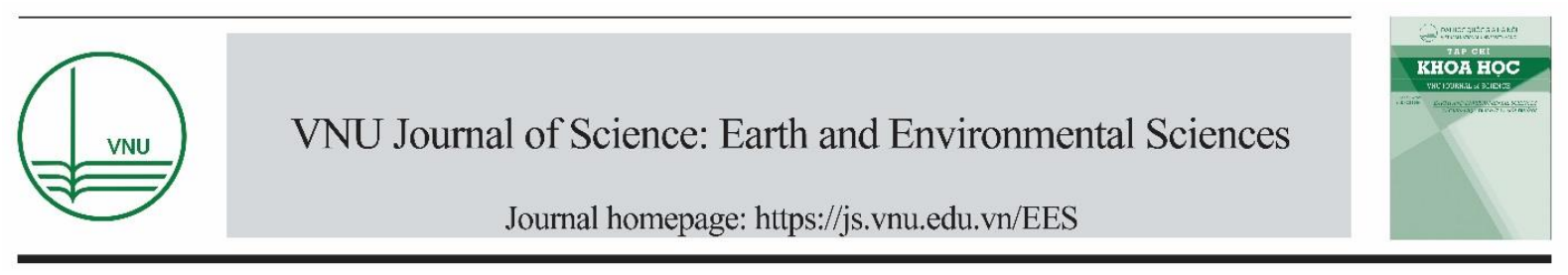

Original Article

\title{
Seismic Refraction Exploration for Groundwater Potential Evaluations: A Case Study of Vientiane Province, Laos
}

\author{
Viengthong Xayavong ${ }^{1,3, *}$, Vu Duc Minh ${ }^{1}$, Nguyen Anh Duong ${ }^{2}$, \\ Vu Minh Tuan ${ }^{2}$
}

${ }^{1}$ VNU University of Science, 334 Nguyen Trai, Hanoi, Vietnam.

${ }^{2}$ Institute of Geophysics, Vietnam Academy of Science and Technology, 18 Hoang Quoc Viet, Hanoi, Vietnam. ${ }^{3}$ Faculty of Natural Science, National University of Laos, Dongdok Campus 7322, Vientiane, Laos.

Received 25 June 2020

Revised 24 August 2020; Accepted 31 August 2020

\begin{abstract}
Recently, there has been increased interest in the use of seismic refraction surveys for the exploration of groundwater investigations. The aim of this study is to delineate groundwater potential zones using the seismic refraction technique. SmartSeis ST, with 12 channels seismograph was selected for seismic refraction data acquisition in Phonhong district of Vientiane Province, Laos. The seismic velocities distribution analysis indicated that there are three different subsurface lithological zones ranging between $(300-750 \mathrm{~m} / \mathrm{s}),(700-1650 \mathrm{~m} / \mathrm{s})$, and $(1500-2100 \mathrm{~m} / \mathrm{s})$. Gradual increase of seismic velocity indicates changes of lithological layers with vertical depth. This velocity increase is due to the dense lithological formation which changes vertically deep from alluvial sediments to dry sand and then to siltstone and gravel layers according to the borehole data. The seismic refraction results show that the aquifer is a sand and gravel aquifer with a thickness of unclear. The depth to the groundwater saturated layers ranging from $10 \mathrm{~m}$ to $25 \mathrm{~m}$. The results of this study have indicated that the application of the seismic refraction exploration method to find groundwater is feasible and effective and can delineate groundwater potential zones in Laos.
\end{abstract}

Keywords: Groundwater, aquifers, seismic refraction exploration, Vientiane, Laos.

\footnotetext{
* Corresponding author.

E-mail address: viengthongxv@gmail.com

https://doi.org/10.25073/2588-1094/vnuees.4651
} 


\section{Introduction}

Groundwater is an essential source as freshwater in around the world, whereas a growing number of countries in Southeast Asia have encountered serious groundwater quantity and quality problems such as declining groundwater tables, subsidence, groundwater quality, and overexploitation leading to unsustainable management of groundwater resources. These are major problems currently challenging hydrogeologists and relevant organizations. Properly managed, groundwater is a renewable resource, with volume varying with the seasons and character of the local geology. Available volumes of surface water may vary very strongly over time, and surface water may be susceptible to various forms of pollution. Groundwater is an important source for irrigation, industries, and for both drinking and domestic purposes, but the mindless pursuit for utilizing more groundwater by all the users has already started conducting tremendous pressure on this essential resource [1].

The potash reserves in the Thangon area of the Vientiane basin are considerable, with an estimated 50.3 billion tonnes of ore grading $15 \%$ potassium chloride [2]. Gypsum is mined e.g. at the Ban Iaomakkha mine in the Savannkhet area to the south, where reserves are estimated to be at least 50 million tonnes. While minerals are significant, the Lao economy is dominated by agriculture, which represents most of the employment in the country and about half of the GDP. Together with the climatic conditions, this means that effective management of water resources is vital for sustained and effective economic growth. As the economy has grown, loads on water resources have increased, requiring more advanced approaches to longterm management.

In Laos, information and programs for the monitoring and evaluation of groundwater quantity and quality are limited. For example, a drilling project in the 1990s in Vientiane Province was implemented by Japan International Cooperation Agency (JICA) for domestic supply in rural areas [3]. Unfortunately, $60 \%$ of the 118 deep wells drilled were could not be used due to poor water quality, such as high salinity [4]. As drilling is expensive, it will be of great benefit if advanced geophysical methods, especially seismic refraction exploration applied as reliable tools for groundwater investigation and management [5]. Nils et al. (2011a) conducted research on characterization of aquifers in the Vientiane Basin, Laos, using Magnetic Resonance Sounding and Vertical Electrical Sounding [20]. Both MRS and VES were carried out at three areas namely Xaythani (Thangon), Thoulakhom and Phonhong districts of Vientiane Basin.

The porous aquifers are described indirectly through the relationship between the lithological features and the body wave velocity. Several approaches have been suggested that the groundwater level is attributed to specific $V_{P}$ values [6-9] or the hypothetic aquifer layer is determined via its $V_{P} / V_{S}$ ratio [10-12] or Poisson's ratio [13]. Besides, the more complex theoretical approaches which are based on the principles of the elastic wave propagation within saturated and unsaturated porous media have been proposed [14]. These approaches require a comprehensive knowledge of the lithological sequences of the investigating site. Meanwhile, Grelle and Guadagno (2009) conducted research entitle seismic refraction methodology for groundwater level determination at three different research sites at Campania region in Italy with the known geological sequences information [15].

In this study, we use the seismic refraction exploration to investigate the groundwater potential at Vientiane Province (Laos). The using of seismic refraction methodology for groundwater level determination of Vientiane Province has never been conducted before. The specific targets are to measure the position of the water table, the thickness of the aquifers, and water quality in these. Results of the field studies are compared to ground-truth from boreholes, including the soil profile. 


\section{Geological Setting}

The Vientiane Basin can be considered as a northwest extension of the Sakon Nakhon basin of the Khorat Plateau, Thailand. The Khorat Plateau covers an area of about $170,000 \mathrm{~km}^{2}$ between latitudes $101^{\circ}$ and $106^{\circ}$ and longitudes $14^{\circ}$ and $19^{\circ}$ in the region of northeastern Thailand and central Laos (Fig. 1). The plateau is mostly gently undulating, without extreme topography, and has an average elevation of about $200 \mathrm{~m}$. The PhuPhan range separates the Khorat Plateau into two basins, namely the Khorat basin in south covering an area of about 36,000 square kilometers and Sakon Nakhon basin in the north covering area of about 21,000 square kilometers [16-20].

The two sites studied are situated in the Vientiane province of Laos. The sedimentary rocks in the Vientiane Basin range from Mesozoic to Cenozoic age. The Mesozoic sedimentary rocks comprise 5 formations, in ascending order name: PhuLekPhai (T1-2pp), Nam Sait (T3ns), PhuPhanang (J-Kpn), Champa (K2cp) and ThaNgon (K2tn) (Fig. 1). These Mesozoic sedimentary rocks are overlain by Quaternary sediments, which are in the Vientiane basin along the valleys of the main rivers consist of gravel, sand and clay including laterite [21]. The correlation between stratigraphy of Khorat Plateau and Vientiane Basin is explained as shown in Table 1. The shallow geological structure of the Vientiane Basin contains alluvium such as sand, gravels and clays (Fig. 1). Groundwater flows from the high land to lower areas of sandstone generally cannot store large quantities of groundwater and communities regularly encounter problems of insufficient yields from shallow wells in the high land areas. Therefore, it's necessary to conduct seismic refraction technique to measure the position of the water table and the thickness of the aquifers in these areas.

Table 1. Stratigraphy of Khorat Plateau and Vientiane Basin

\begin{tabular}{|c|c|c|c|c|c|}
\hline \multicolumn{3}{|c|}{$\begin{array}{l}\text { Khorat Plateau, Thailand } \\
\text { (modified from [22]) }\end{array}$} & \multicolumn{3}{|c|}{$\begin{array}{l}\text { Vientiane Basin, Laos } \\
\text { (modified from [21]) }\end{array}$} \\
\hline Age & Formation & $\begin{array}{l}\text { Thickness } \\
(m)\end{array}$ & Age & Formation & $\begin{array}{l}\text { Thickness } \\
\text { (m) }\end{array}$ \\
\hline & & & \multirow{4}{*}{$\begin{array}{l}\text { Neogene } \\
\text { Quaternary }\end{array}$} & Vientiane & \\
\hline & & & & $(\mathrm{Q} 4)$ & 0.5 \\
\hline & & & & $(\mathrm{Q} 2-3)$ & $20-25$ \\
\hline & & & & (N2Q1) & 70 \\
\hline $\begin{array}{l}\text { Cretaceous- } \\
\text { Tertiary }\end{array}$ & PhuThok (KTpt) & $50-785$ & \multirow[t]{2}{*}{ Cretaceous } & \multirow{2}{*}{$\begin{array}{l}\text { ThaNgon } \\
\text { (K2tn) }\end{array}$} & \multirow{2}{*}{$>500$} \\
\hline $\begin{array}{l}\text { Cretaceous- } \\
\text { Tertiary }\end{array}$ & $\begin{array}{l}\text { MahaSarakham } \\
\text { (KTms) }\end{array}$ & $156-1294$ & & & \\
\hline Cretaceous & KhokKruat (Kkk) & $100-350$ & Cretaceous & $\begin{array}{l}\text { Champa } \\
\text { (K2cp) }\end{array}$ & 400 \\
\hline Cretaceous & PhuPhan (Kpp) & $120-150$ & \multirow{3}{*}{$\begin{array}{l}\text { Jurassic- } \\
\text { Cretaceous }\end{array}$} & \multirow{3}{*}{$\begin{array}{l}\text { PhuPha Nang } \\
\text { (J-Kpn) }\end{array}$} & \multirow{3}{*}{350} \\
\hline Cretaceous & Sao Khua (Ksk) & $280-420$ & & & \\
\hline $\begin{array}{l}\text { Jurassic- } \\
\text { Cretaceous }\end{array}$ & PraWiharn (JKpw) & $56-136$ & & & \\
\hline Cretaceous & PhuKradung (Jpk) & $800-1100$ & Middle Triassic & Nam Sait (T3ns) & $700-850$ \\
\hline Triassic & Nam Phong (Trnp) & $600-750$ & $\begin{array}{l}\text { Early-Middle } \\
\text { Triassic }\end{array}$ & $\begin{array}{l}\text { PhuLekPhai } \\
\text { (T1-2pp) }\end{array}$ & 650 \\
\hline
\end{tabular}




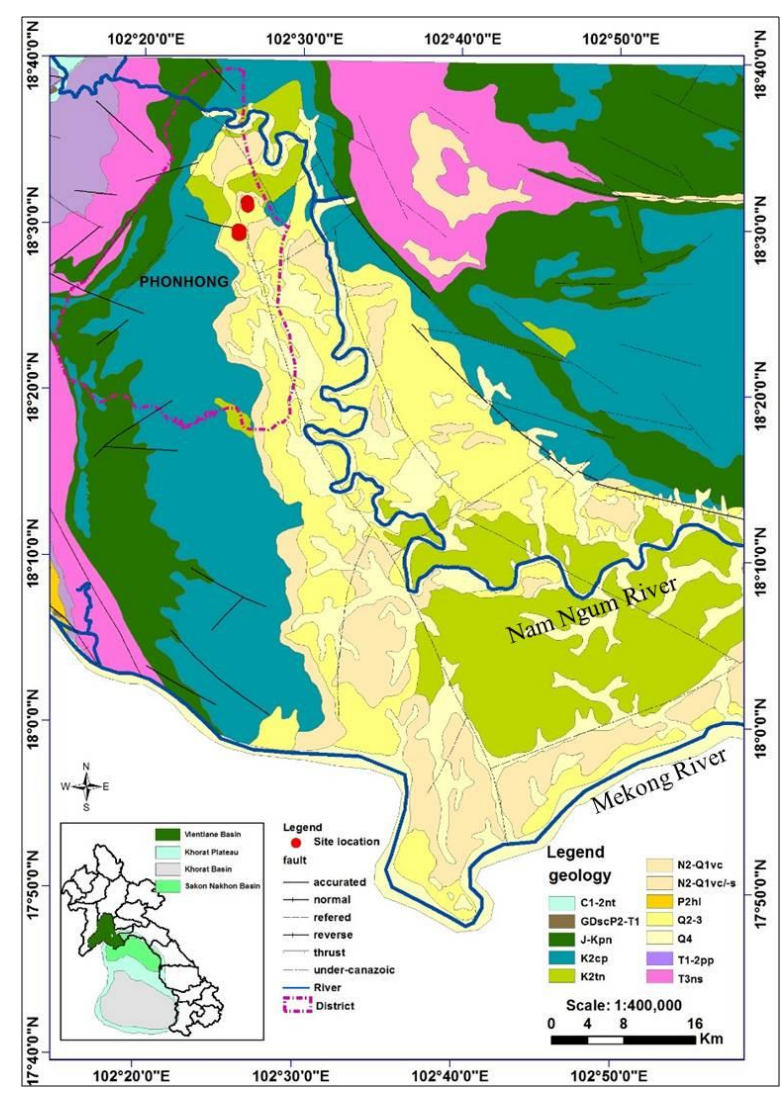

Figure 1. Geology of Vientiane Basin [23], key map showing the extent of Khorat Plateau and the site locations [16].

\section{Data and Method}

\subsection{Seismic refraction exploration}

The seismic refraction exploration applies seismic energy that returns to the surface after travelling through the earth subsurface along refracted ray paths. The seismic technique is based on a seismic wave's propagation in the subsurface, which depends on the velocity variation in difference medium, but it is applicable in cases where velocity varies smoothly as a function of depth. The thickness and velocity of ground between an interface can be calculate by determining the arrival times for direct and refracted waves from seismic section. The velocities of longitudinal waves, $\mathrm{P}$-wave, $V_{P}$ and of transverse waves, $\mathrm{S}$-wave, $V_{S}$ in a homogeneous and isotropic medium are given by the equation (1). The factors affecting seismic velocity depend on their various compositions, textures (i.e. grain shape and degree of sorting), porosities and contained pore fluids, rocks differ in their elastic moduli and densities (Table 2) shows seismic velocity value varies with mineral content, lithology, porosity, density and degree of compaction [24]

$$
V_{P}=\sqrt{\frac{\lambda+2 \mu}{\rho}} \text { and } V_{S}=\sqrt{\frac{2 \mu}{\rho}} .
$$

By virtue of their various compositions, textures, e.g. grain shape and degree of sorting, porosities and contained pore fluids, rocks differ in their elastic moduli and densities and, hence, in their seismic velocities. Information on the compressional and shear wave velocities, $V_{P}$ and $V_{S}$, of rock layers encountered by seismic surveys is important for two main reasons: firstly, it is necessary for the conversion of seismic wave travel times into depths; secondly, it provides an indication of the lithology of a rock [24].

The relationship between earth subsurface proprieties and body wave velocity has been studied for many years, as a means of indirectly characterizing porous aquifers. In existing literature, different approaches have been proposed some cases the water table is attributed to specific primary wave velocity $\left(V_{P}\right)$ values. In the seismic refraction method, the magnitude of wave velocity values for the estimation of the depth of the aquifer has ambiguity for interpretation because a wide range of $V_{P}$ values in connection to the water table level and these values are not uniquely correlated to the aquifer layer. Some authors attribute P-wave velocities around $1500 \mathrm{~m} / \mathrm{s}$ to represent a saturated layer [15]. Meanwhile, another report proposes a Pwave velocity between 1200 and $1800 \mathrm{~m} / \mathrm{s}$ in porous aquifers [9].

\subsection{Data acquisition}

The two study sites in Phonhong district of Vientiane province is situated in the Vientiane Plain is a large area of around 4,500 $\mathrm{km}^{2}$ (Fig. 2), where is located in the central region of Laos 
with a population of around 800,000 . Annual rainfall is around $2,500 \mathrm{~mm}$ but is largely concentrated within the five-month-long rainy season. The flat lowland with elevations vary from 170 to190 meters above sea level are flanked to the east and west by mountains covered by forests with elevations ranging up to 1600 meters and by the Mekong River to the south (Fig.1). Laos has tropical monsoon climate with a rainy from May to October, followed by a cool dry season from November to February and a hot dry season from March to April [25].

The SmartSeis ST with 12 channels seismograph was selected for seismic refraction exploration at the two study sites for 4 seismic profiles (Fig.2 and 3), which seismic survey profile length of $440 \mathrm{~m}$, with geophone interval of $5 \mathrm{~m}$, and consists of 8 spreads for each seismic profile. The technique consisted of laying out 12 geophones in a straight line and recording arrival times from shot points produced by striking a 5 $\mathrm{kg}$ sledge hammer into a steel plate at 7 shots per spread: one inter-spread shot, three forward and three reverse shots (Fig.4). Seismographs setting for data acquisition for each profile at two sites are the same. The first geophones of spread 1 located at $0 \mathrm{~m}$ and the $12^{\text {th }}$ geophone at $55 \mathrm{~m}$; while the first geophone of spread 2 located at 55 $\mathrm{m}$ and the $12^{\text {th }}$ geophone at $110 \mathrm{~m}$ then move to next spread until reach to the first geophone of spread 8 located at $385 \mathrm{~m}$ and the $12^{\text {th }}$ geophone at $440 \mathrm{~m}$.

Table 2. The P-wave velocity of various earth materials

\begin{tabular}{|l|r|}
\hline \multicolumn{1}{|c|}{ Materials } & \multicolumn{2}{c|}{ P-wave velocity (m/s) } \\
\hline Air & 331.5 \\
\hline Water & $1400-1600$ \\
\hline Sandstone and shale & $2000-4500$ \\
\hline Limestone & $2000-6000$ \\
\hline Sand and gravel & $500-1500$ \\
\hline Shale & $2000-4500$ \\
\hline Conglomerate & $10-800$ \\
\hline Alluvium & $500-2000$ \\
\hline Sand (dry) & $200-1000$ \\
\hline Sand (Saturated) & $1500-2000$ \\
\hline Clay & $1000-2500$ \\
\hline
\end{tabular}

\subsection{Data processing}

The SeisImager software performed for seismic refraction data interpretation in order to map subsurface geology in the study area. This software has a system package for picking the first arrival time for $\mathrm{P}$-wave known as the PickWin program. This software uses nonlinear traveltime tomography consisting of ray tracing for forward modeling and simultaneous iterative reconstruction technique (SIRT) for inversion. The main features of the algorithm are: an initial model is constructed so that the velocity is layered and increased with depth, the first arrival traveltimes and ray paths are calculated by the ray tracing method based on the shortest path calculation as described by Moser (1991) and a traveltime between a source and a receiver is defined as the fastest traveltime of all ray paths. The velocity model is updated by SIRT and the seismic velocity of each cell is also updated during the process [26]. The flow chart of seismic refraction data processing (Fig.5) and the procedures in seismic refraction inversion processes are explained as flowing:

(1) The field data file is based on readable file format of the software for the data analysis and processing.

(2) Gain control is conducted to the data to accentuate weak arrival times and other wavelets to improve the quality of the wavelet traces when to be picked.

(3) First arrival times are manually picked through visual inspection from collected time record on software like PickWin and saved for subsequent analysis.

(4) A traveltime curve is generated through the layer assignment technique in interpretation model like Plotrefa.

(5) The model is divided into a large number of smaller constant velocity grid cells. The model is then inverted by performing ray tracing with the grid cells adjusted in an attempt to match the calculated traveltimes to produce a $2 \mathrm{D}$ initial velocity model.

(6) This is repeated until the number of predefined iterations within the software has been 
completed as the resulting final subsurface model or earth velocity model.

Because the seismic profiles were acquired on generally flat ground, timing corrections due to elevation variation along the profiles were unnecessary. The velocity model is inverted by performing ray tracing, via an initial velocity model and comparing the modelled traveltimes to field data, and adjusting the model grid-by grid in order to match the calculated traveltimes to the field data. This then generates the resulting subsurface velocity model also known as tomogram /inverted velocity model after the number of program predefined iterations has been completed.

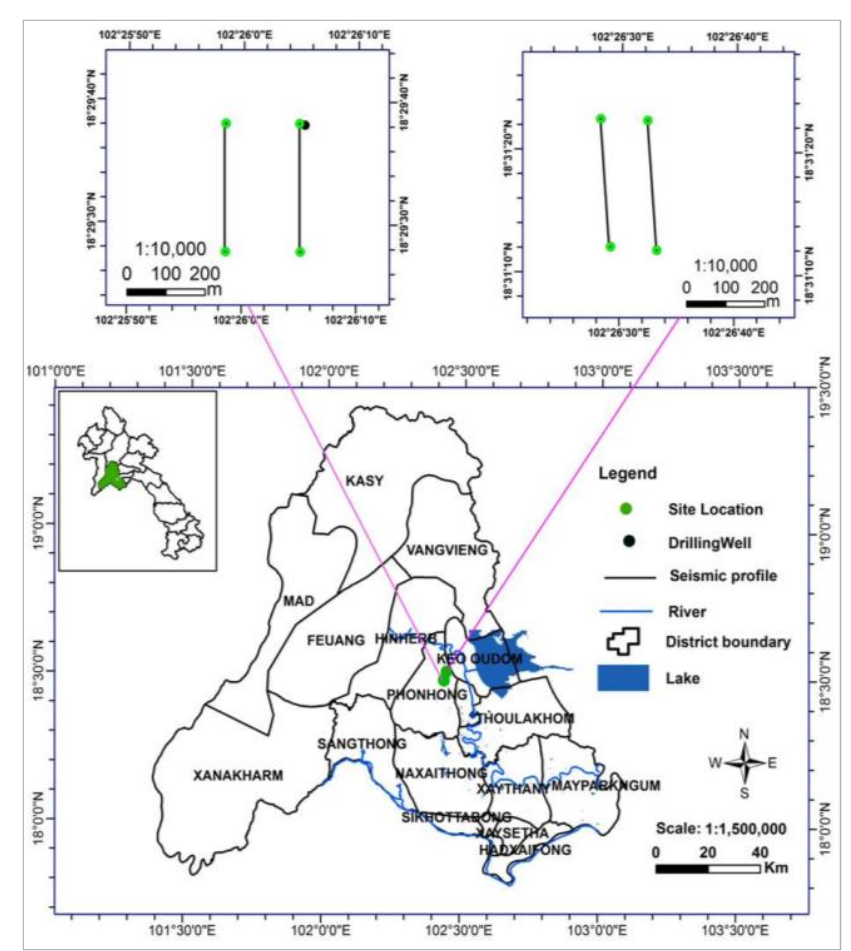

Figure 2. Location of the orientation of seismic refraction survey profiles.

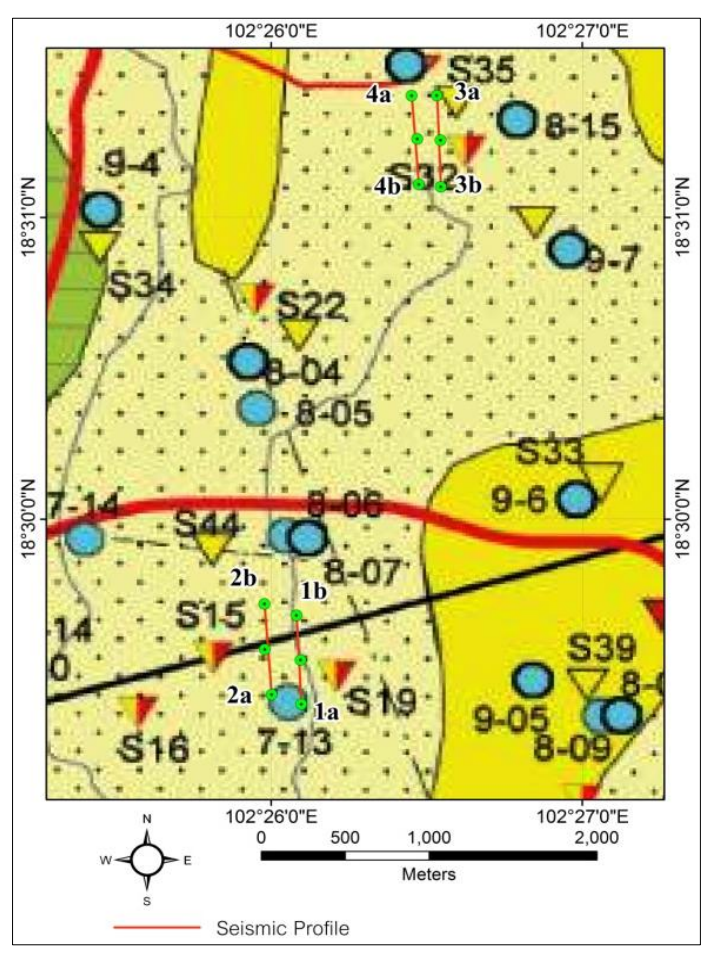

Figure 3. Location of the orientation of seismic refraction survey profiles compared with geophysical sites of Nils et al. (2011a).

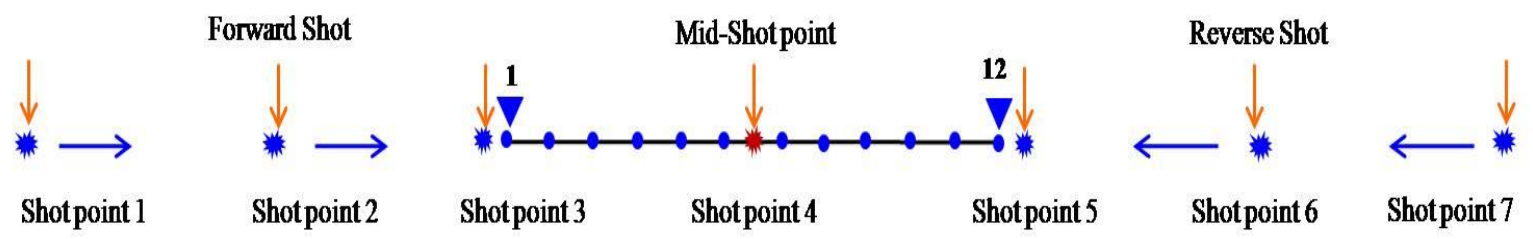

Figure 4. A typical seismic refraction data acquisition layout and location of shot points for seismic refraction survey profile. 


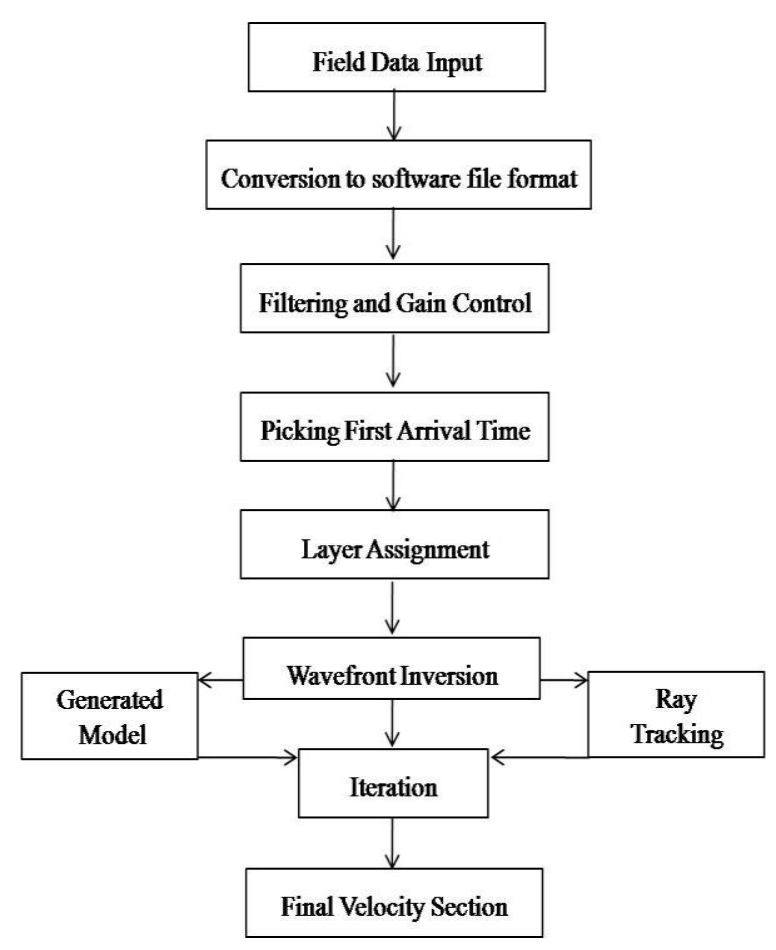

Figure 5. Flow chart of seismic refraction data processing.

\section{Results and Discussion}

The results obtained from the seismic refraction data analysis in the two sites revealed these regions can be categorized as a three earth layers with the velocity of each layer increasing with depth in the composition of the earth subsurface. Two parallel south-north transverse seismic profiles namely profile 1 and 2 at sites 1 showed similar result. The traveltime curves and velocity models are shown in (Fig. 6 and 7). The P-wave velocity of topmost layers, where lowest seismic velocities ranging from 300 to $700 \mathrm{~m} / \mathrm{s}$ with an average velocity of $500 \mathrm{~m} / \mathrm{s}$ were detected, corresponds to an area within the sand and clay top soil which is mainly as dry alluvial sediments, whereas the thickness of the first layers range from 0 to $5 \mathrm{~m}$. The second layers found the yellowish green colours and seismic velocity vary from 700 to $1500 \mathrm{~m} / \mathrm{s}$ with an average of $1100 \mathrm{~m} / \mathrm{s}$, corresponds to an area which is mainly thick saturated clayey layer and the thickness of the second layers range between $5 \mathrm{~m}$ to $15 \mathrm{~m}$. The third layers found blue colours and seismic velocity range from 1500 to 2000 $\mathrm{m} / \mathrm{s}$ with an average of $1750 \mathrm{~m} / \mathrm{s}$, corresponds to an area which is mainly gravel and siltstone with the depth from ground surface to the third layer is greater than $15 \mathrm{~m}$ indicating suitable areas for groundwater potential zones. It is clearly when we compare the velocity with that of water or sand (saturated) materials in Table 2.

Meanwhile, two parallel north-south transverse seismic profiles namely profile 3 and 4 at site 2 showed similar results. The traveltime curves and velocity models are shown in (Fig. 8 and 9). The P-wave velocity of topmost layers, where lowest seismic velocities ranging from 300 to $750 \mathrm{~m} / \mathrm{s}$ with an average velocity of $525 \mathrm{~m} / \mathrm{s}$ were detected, corresponds to an area within the sand and clay top soil which is mainly as dry alluvial sediments, whereas the thickness of the first layers range from 5 to $10 \mathrm{~m}$. The second layers made up of the yellowish green colours and seismic velocity ranges from 750 to $1650 \mathrm{~m} / \mathrm{s}$ with an average of $1200 \mathrm{~m} / \mathrm{s}$ were detected, corresponds to an area which is mainly thick saturated clayey layer and the thickness of the second layer ranges between 10 to $20 \mathrm{~m}$. The third layers made up blue colours and seismic velocity range from 1650 to $2100 \mathrm{~m} / \mathrm{s}$ with an average of $1875 \mathrm{~m} / \mathrm{s}$ were detected, corresponds to an area which is mainly gravel and siltstone with the depth from ground surface to the third layer is greater than $20 \mathrm{~m}$ indicating suitable areas for groundwater potential zones. 

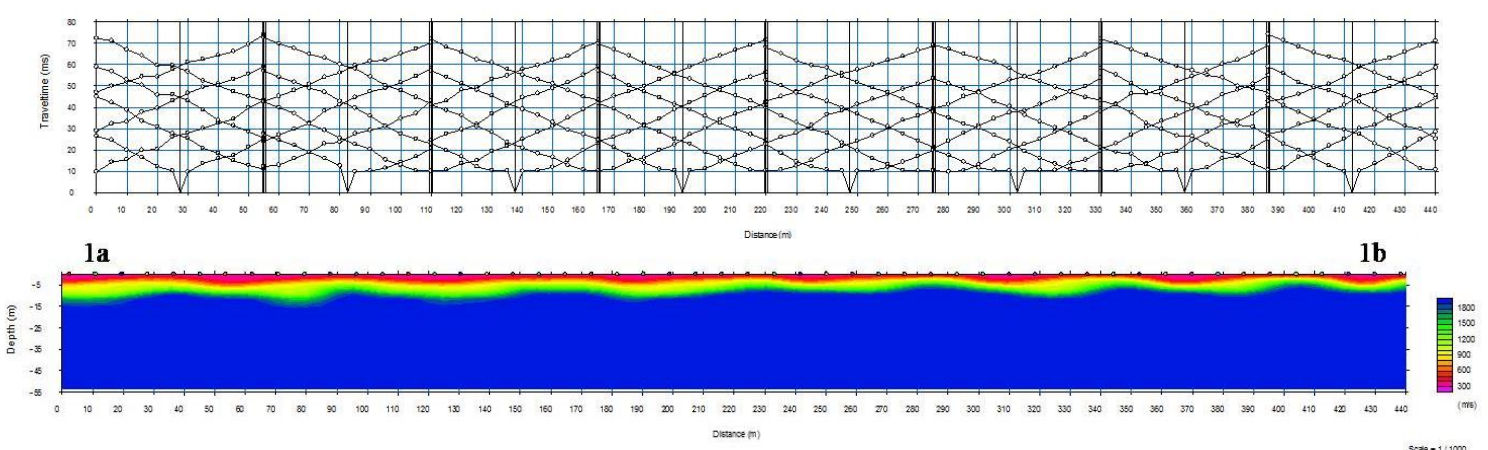

Figure 6. The traveltime curves and velocity models for seismic profile 1 at site 1 .
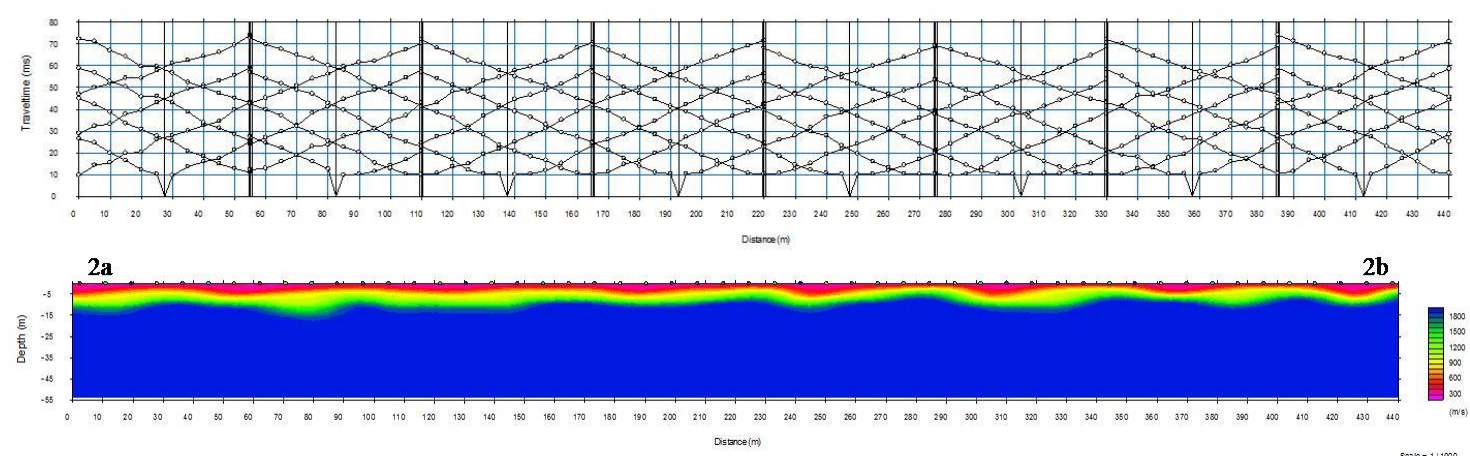

Figure 7. The traveltime curves and velocity models for seismic profile 2 at site 1.

The results of seismic refraction technique found the depth of the main aquifer ranges from 18 to $20 \mathrm{~m}$ that respond well with Magnetic Resonance Sounding and Vertical Electrical Sounding at three areas namely Xaythani (Thangon), Thoulakhom and Phonhong districts of Vientiane Basin [27]. The results from the MRS measurements show that the aquifer thickness ranges from 10 to $40 \mathrm{~m}$ and the depth of the main aquifer ranges from 5 to $15 \mathrm{~m}$ [27]. The free water content is up to $30 \%$ and the decay times vary between 100 and $400 \mathrm{~ms}$, suggesting a mean pore size equivalent to fine sand to gravel while the resistivity of the aquifers is highly variable but is usually higher than 10 $\Omega-m$ suggesting that the water is fresh [27]. Meanwhile, determining water quality parameters of aquifers in the Vientiane basin, Laos used geophysical and water chemistry data [28]. The results found water layers are identified with the main water layer situated between 13-30 $\mathrm{m}$ in depth with no water below [28]. From the VES models it becomes clear that the low-resistive layer $(3 \Omega \mathrm{m})$ starts between
34-37 m, which is an indication that this layer is most likely clay (Fig.11) [21]. In additionally, drilling found the water table at a depth of $20 \mathrm{~m}$ in Phonhong district. Soil samples collected from this depth have been identified as gravel and siltstone, matching the velocity model result. The detailed soil profile is included in Fig. 10b. The different geological formations observed from the borehole 1 (BH 1) stratigraphy data matched well with the seismic results (Table 3).

Integrated seismic and drilling results at seismic profile 1 where is Naxou village, which correlated well with vertical electrical sounding at site S19 of Nils et al. (2011a) (Fig.3), indicated that found water table range from 15 to $30 \mathrm{~m}$ with average seismic velocity around $1875 \mathrm{~m} / \mathrm{s}$ is considered as gravel and siltstone aquifers in research sites. According to the seismic exploration results, the thickness of all three layers of Site 2 at Phonhor village is larger than that of Site 1 at Naxou village. It means that the aquifer layer (N2Q1) at Site 2 is thicker than that at Site 1. 


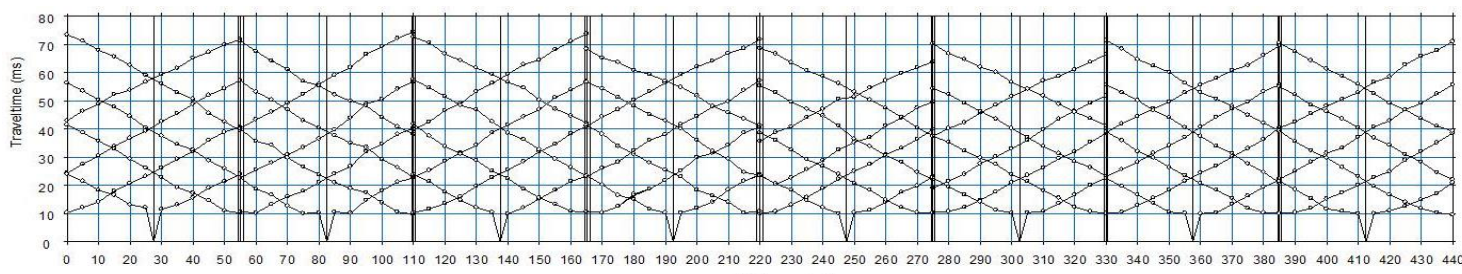
Distance $(m)$

Scale $=1 / 1000$

3a

$3 \mathrm{~b}$

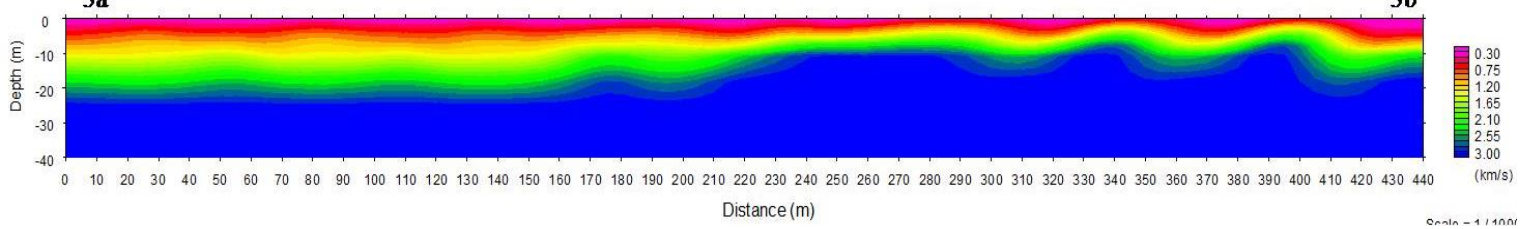

Figure 8. The traveltime curves and velocity models for seismic profile 3 at site 2 .

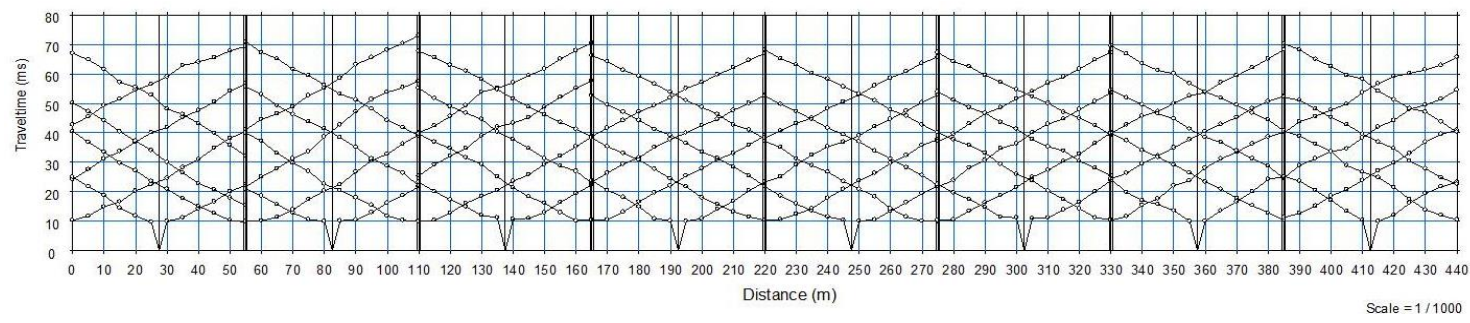

4a

$4 \mathrm{~b}$

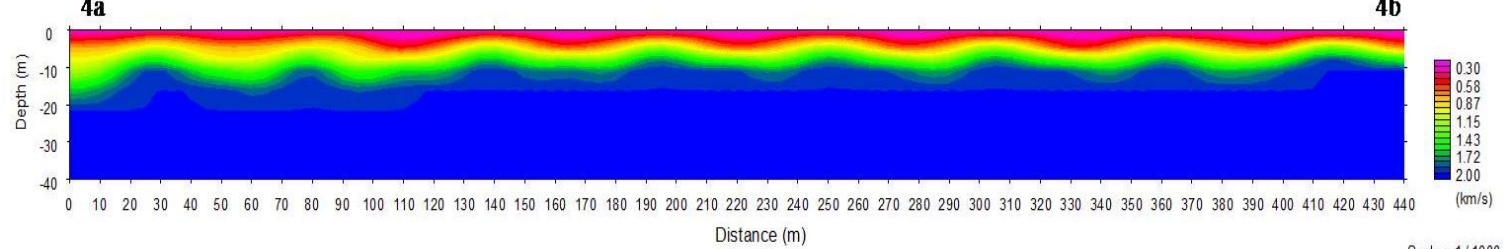

$$
\text { Distance ( } m \text { ) }
$$

Figure 9. The traveltime curves and velocity models for seismic profile 4 at site 2 .

Table 3. Comparison between drilling results at BH 1 and seismic result of velocity model

\begin{tabular}{|c|c|c|c|c|}
\hline \multicolumn{2}{|c|}{ Drilling results at $\mathrm{BH} 1$} & \multicolumn{3}{|c|}{ Velocity model results at profile 1} \\
\hline Depth (m) & Stratigraphy & Depth $(\mathrm{m})$ & Velocity range $(\mathrm{m} / \mathrm{s})$ & Stratigraphy \\
\hline $0-5$ & Clay and sand top soil & \multirow{3}{*}{$0-10$} & \multirow{3}{*}{$300-750$} & \multirow{3}{*}{ Clay and sand top soil } \\
\hline $5-8$ & Sandy and clay & & & \\
\hline $8-12$ & Clay and sand & & & \\
\hline $12-15$ & Mudstone and clay & \multirow{3}{*}{$10-20$} & \multirow{3}{*}{$750-1650$} & \multirow{3}{*}{ Sandy clay } \\
\hline $15-20$ & Sand & & & \\
\hline $20-22$ & $\begin{array}{l}\text { Gravel and siltstone } \\
\text { (water table) }\end{array}$ & & & \\
\hline $22-25$ & Siltstone & $>20$ & $1650-2100$ & $\begin{array}{l}\text { Gravel and siltstone } \\
\text { (water table, aquifers) }\end{array}$ \\
\hline
\end{tabular}




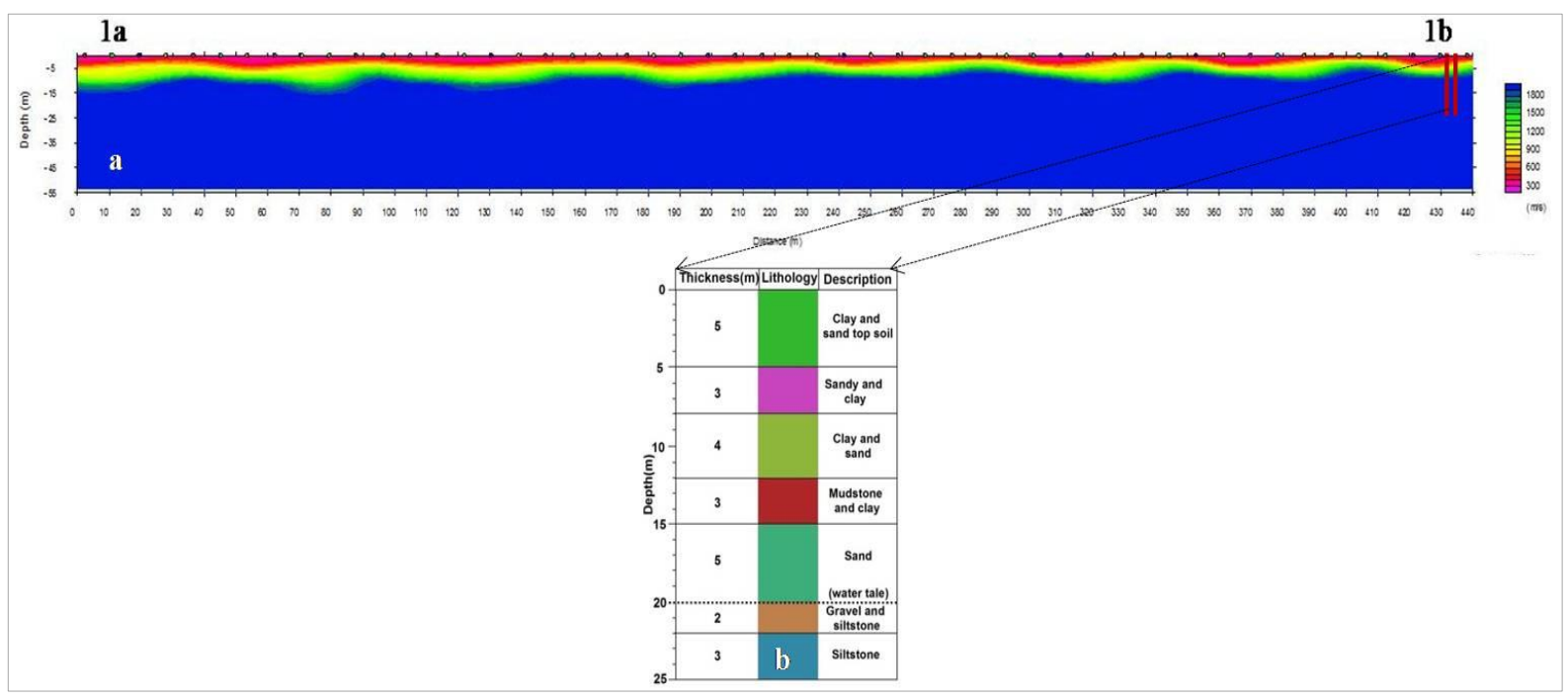

Figure 10. (a) Seismic velocity model under profile 1 at site 1 and (b) vertical geological section of borehole $1(\mathrm{BH} 1)$ at $440 \mathrm{~m}$ along profile 1 .

\section{Conclusion}

The seismic refraction exploration method has proved useful in subsurface mapping in earth layers depends on depth. In Phonhong district, the average seismic velocities of $600 \mathrm{~m} / \mathrm{s}$ for the upper layer, interpreted as alluvium sediments with thickness of $5 \mathrm{~m}$. The middle layer has a thickness of $14 \mathrm{~m}$ and average seismic velocities of $1200 \mathrm{~m} / \mathrm{s}$ and is interpreted as thick saturated clayey layer. Third layer's average velocities are $1750 \mathrm{~m} / \mathrm{s}$ and are interpreted as gravel and siltstone (water saturated) with $18 \mathrm{~m}$ vertical extensions. This result is agreement with the drilling results of borehole 1 at site 1 in the Phonhong district found the water table at depth $20 \mathrm{~m}$ and the soil sample collected at this depth has been identified as gravel and siltstone. According to velocity and lithology of third layer, which could form good reservoir for groundwater potential, were identified. The change in velocity may largely be as a result of the variation in subsurface lithology, texture, structure, grain size, compaction, cementation and the level of groundwater saturation. Thickness of all three layers has gradually increasing from northern to southern part of the study site 2 . The results of this research work have indicated that the application of the seismic refraction exploration method to find groundwater in Laos is feasible and effective and can delineate groundwater potential zones in the study areas.

\section{Acknowledgements}

The authors are grateful to the International Science Programme (ISP) of Uppsala University, Sweden for funding the research work. The authors would like to express our deepest appreciation to Department of Physics, Faculty Natural Science, National University of Laos for supporting the SmartSeis ST (USA) and Department of Geology and Mines of Laos for geological information in the study areas.

\section{References}

[1] H. Kyoochul, T.M.N. Nguyen, L. Eunhee, J. Ramasamy, Current Status and Issues of Groundwater in the Mekong River Basin, Korea Institute of Geoscience and Mineral Resources (KIGAM) (2017) 1-125. https://bangkok.unesco. org/content/current-status-and-issues-groundwater -mekong-river-basin (accessed 16 April 2020). 
[2] M. Masaharu, Final Report for Economic Geology, the World Bank Washington DC (2006).

[3] Japan International Cooperation Agency (JICA). The study on rural water supply and sanitation improvement in the northwest region in the Lao People's Democratic Republic, Ministry of health, National centre for environmental health and water supply, Progress report 2 (2000) 14.

[4] K. Takayanagi, Basic Design Study Report on the Project for Groundwater Development in Vientiane Province in Laos PDR, Japan International Cooperation Agency (JICA) (1993).

[5] C. Chiemeke, and Aboh, Delineation of aquiferous layers within the basement complex using joint inversion of seismic refraction tomography and high resolution 3D seismic reflection survey, Arch. Applied Sci. Res 4 (2012) 400-405. https://www. researchgate.net/publication/282768427_Delineati on_of_aquiferous_layers_within_the_basement_c omplex_using_joint inversion_of_seismic_refract ion_tomography_and_high_resolution_3D_seismi c_reflection_survey (accessed 16 April 2020).

[6] A.A.R Zohdy, G.P. Eaton, D.R. Mabey,1974. Application of surface geophysics to groundwater investigation. U.S. Geol. Surv. Techniques of Water Resource Investi- gations, book 2, chapter D1.

[7] J.E. Sander, The blind zone in seismic groundwater exploration, Ground Water 165 (1978) 394 395. https://doi.org/10.1111/j.1745-6584.1978.tb0 3252.x

[8] F.P. Haeni, Application of seismic refraction methods in groundwater modelling studies in New England. Geophysics 51 (2) (1986) 236-249. http:// dx.doi.org/10.1190/1.1442083.

[9] B. Hasselstroem, Water prospecting and rockinvestigation by the seismic refraction method. Geoexploration 7 (2) (1969) 213. https://doi.org/ 10.1016/0016-7142(69)90026-X.

[10] H. Stümpel, S. Kähler, R. Meissner, B. Milkereit, The use of seismic shear waves and compressional waves for lithological problems of shallow sediments. Geophysical Prospecting 32 (1984) 662-675. https://doi.org/10.1111/j.1365-2478. 1984.tb01712.x.

[11] J.P. Castagna, M.L. Batzle, R.L. Eastwood, Relationship between compressional-wave and shear-wave velocities in clastic silicate rocks. Geophysics 50 (4) (1985) 571-581. https://doi.org/ 10.1190/1.1894108.

[12] C. Nicholson, D.W. Simposon, Changes in $V_{P} / V_{S}$ with depth: implication for appropriate velocity models, improved earthquake locations, and material proper- ties of the upper crust. Bulletin of the Seismological Society of America 75 (1985)
1105-1124. https://pubs.geoscienceworld.org/ssa/ bssa/article-abstract/75/4/1105/118773/Changesin-Vp-Vs-with-depth-Implications-for?redirected From=fulltext (accessed 16 April 2020).

[13] J.M. Lees, H. Wu, Poisson's ratio and porosity at Coso geothermal area, California. Journal of volcanology and geothermal research 95 (2000) 157-173. https://doi.org/10.1016/S0377-0273(99) 00126-2.

[14] S. Foti, C.G. Lai, R. Lancellotta, Porosity of fluidsaturated porous media from measured seismic wave velocities. Geotechnique 52 (5) (2002), 359373. http://dx.doi.org/10.1680/geot.52.5.359.38702.

[15] G. Grelle, F.M. Guadagno, Seismic refraction methodology for groundwater level determination: "Water seismic index". Journal of Applied Geophysics 68 (2009) 301-320. https://doi.org/10. 1016/j.jappgeo.2009.02.001.

[16] M. El Tabakh, C. Utha-Aroon, B.C. Schreiber, Sedimentology of the Cretaceous Maha Sarakham evaporites in the Khorat Plateau of northeastern Thailand, Sedimentary Geology 123 (1999) 31-62. https://doi.org/10.1016/S0037-0738(98)00083-9.

[17] R.J. Hite, W. Japakasert, Potash deposits of the Khorat Plateau, Thailand and Laos, Economic Geology 74 (1979) 448-458. http://dx.doi.org/10. 2113/gsecongeo.74.2.448.

[18] S. Keith, P. Crosby, Overview of the Geology and Resources of the APPC Udon Potash (Sylvinite) Deposits, Udon Thani Province, Thailand. International Conference on Geology, Geotechnology and Mineral Resources of Indochina (GEOINDO 2005), Khon Kaen, Thailand (2005) 283-299. http://amdis.bgl.esdm. go.id/index.php/9-mineral-article-1/mineralarticle/130-overview-of-the-geology-andresources-of-the-appc-udon-potash-sylvinitedeposits-udon-thani (accessed 16 April 2020).

[19] F.L.S. Paul, B.S. Robert, B. Charlie, C. Andrew, Mid-Cretaceous inversion in the Northern Khorat Plateau of Lao PDR and Thailand, Tectonic Evolution of Southeast Asia, 106 (2016), 233-247. http://dx.doi.org/10.1144/GSL.SP.1996.106.01.15

[20] Z. Xiying, M. Haizhou, M. Yunqi, T. Qiliang, Y. Xiaolong, Origin of the late Cretaceous potashbearing evaporites in the Vientiane Basin of Laos, Journal of Asian Earth Sciences 62 (2013) 812818. https://doi.org/10.1016/j.jseaes.2012.11.036.

[21] K. Phommakaysone, Urban geology of Vientiane municipality, capital of the Lao people's Democratic Republic, Atlas of Urban Geology 14 (2001) 341-346.

[22] M. Raksaskulwong, D. Monjai, Relationship between the Maha Sarakham Formation and high 
terrace gravels along the Khon Kean-Kalasin provinces. (Geothai'07), Department of Mineral Resources, Bangkok, Thailand (2007) 288-296. http://library.dmr.go.th/Document/ProceedingsYearbooks/M_1/2007/12735.pdf (accessed 16 April 2020).

[23] N.X. Long, N.X. Lam, N.D. Canh, Report on Geological data for Potassium and Manganese in Thangon. Department of Geology and Mining, Vientiane, Laos (1986).

[24] P. Kearey, M. Brooks, I. Healy, An Introduction to Geophysical Exploration. 3rd ed. Blackwell Science (2002).

[25] M. Stuart-Fox, D.F. Rooney. Microsoft Encarta, (2006).

[26] S.A. Adedibu, C.O. Abimbola. Insight into seismic refraction and electrical resistivity tomography techniques in subsurface investigations, The Mining-Geology-Petroleum Engineering Bulletin (2019) 93-111. http://dx.doi.org/10.17794/rgn. 2019.1.9.

[27] P. Nils, W. Kamhaeng, P. Khamphouth, E. StenAke, Characterization of aquifers in the Vientiane Basin, Laos, using Magnetic Resonance Sounding and Vertical Electrical Sounding. Journal of Applied Geophysics 73 (2011a) 207-220. https:// doi.org/10.1016/j.jappgeo.2011.01.003.

[28] P. Nils, W. Kamhaeng, P. Khamphouth, E. StenAke, Determining water quality parameters of aquifers in the Vientiane Basin, Laos, using geophysical and water chemistry data, Near Surface Geophysics 9 (2011b) 381-395. https://doi. org/10.3997/1873-0604.2011014. 